\title{
PENCATATAN PERKAWINAN DALAM TEKS PERUNDANG-UNDANGAN PERKAWINAN DI BEBERAPA NEGARA ISLAM PERSPEKTIF USUL FIKIH
}

\author{
Supani \\ STAIN Purwokerto \\ Jl. A.Yani No. 40 A Purwokerto \\ Email: supanip@yahoo.com
}

\begin{abstract}
The provisions on marriage registration law are not explicitly stated by the texts of the Qur'an and Sunnah, albeit marriage is a legal event, creating rights and obligations of the parties. The fulfillment of these rights and obligations can be well enforced if an orderly marriage administration is in place, namely by registering the marriage to the competent institutions of marriage, evidenced by a marriage certificate (authentic evidence). Since the texts do not provide the laws, its explanation is also not found in conventional fikih. Marriage laws in several Islamic countries also provide non-uniform provisions in terms of technical details, although the majority requires marriage registration. The legal importance of marriage registration can be strengthened by several methods of istinbath (usul fikih), inter alia, the methods of qiyās, sadd al-żari'ah, and al-mașlaḥat almursalah. respectively.
\end{abstract}

Kata kunci: Usul fikih, pernikahan yang tidak dicatatkan, pencatatan pernikahan,hukum perkawinan, negara-negara Islam

\section{A. Pendahuluan}

Pembahasan mengenai pencatatan perkawinan dalam kitab-kitab fikih tradisional tidak ditemukan. Karena tidak disebutkan dalam fikih, maka umat Islam yang berfikir fikih sentris menganggap remeh dan cenderung mengabaikan pencatatan perkawinan oleh lembaga negara yang berwenang untuk itu. Bahkan dijumpai juga pandangan, bahwa perkawinan adalah urusan pribadi (individual affairs) setiap muslim, karena itu pemerintah tidak perlu campur tangan pada wilayah pribadi ini. Di sisi lain sebagian masyarakat muslim yang menggunakan paradigma berfikir fikih dan perundang-undangan sekaligus, berusaha terus mensosialisasikan manfaat dan keuntungan adanya ketentuan pencatatan perkawinan ini terutama untuk istri dan anak-anak. Munculnya dua pandangan masyarakat muslim ini disebabkan oleh tidak adanya ketentuan dalam al-Qur'an dan Hadis yang secara tekstual mengatur mengenai keharusan pencatatan perkawinan.

Pencatatan perkawinan bagi umat muslim menjadi trend bahkan menjadi kebutuhan bagi kehidupan keluarganya. Buktinya, ketentuan tentang pencatatan perkawinan disebutkan dalam peraturan perundang-undangan perkawinan muslim di beberapa negara Islam selain Al-Jazair seperti Indonesia, Malaysia, Brunei, Singapura, Mesir, Iran, Libanon, Syiria, Pakistan, Libya, Yordan, dan Yaman dengan berbagai variasi ketentuan.

Kasus-kasus nikah sirri atau nikah di bawah tangan yang dilakukan masyarakat adalah sebuah realitas yang harus dijadikan pertimbangan dan dasar bagi yuris muslim dalam merumuskan 
hukum Islam baik yang berupa fikih maupun peraturan perundang-undangan di suatu negeri, agar hukum Islam tidak dibuat berdasarkan asumsi-asumsi belaka tanpa melihat data empirik yang ada di negeri itu. Demikian halnya dengan urgensi pencatatan perkawinan hendaknya dikaji untuk mendapatkan relevansinya dengan realitas yang ada. Karena tidak ada satu pun nash baik alQur'an maupun hadis yang konkrit menjelaskan keharusan pencatatan perkawinan, maka diperlukan ijtihad para yuris Islam untuk mendapatkan status hukumnya. Untuk sampai pada kesimpulan hukum yang berbobot, para yuris Islam dalam melakukan ijtihad, menggunakan metode ijtihad (usul fikih) secara tepat dengan menggali illat hukumnya secara tepat pula. Di sinilah perlunya penelitian literer ini dilakukan untuk mengungkap landasan metodologis dalam menentukan perlu tidaknya pencatatan perkawinan. Persoalan pokok dalam penelitian ini adalah bagaimana ketentuan pencatatan perkawinan ditinjau dari usul fikih? Fokus penelitian ini untuk mencari landasan metodologis bagi ketentuan perlu dan tidaknya pencatatan perkawinan. Pokok masalah tersebut dapat dijabarkan menjadi dua pertanyaan, yaitu: (1) Bagaimana ketentuan pencatatan perkawinan dalam perundangundangan perkawinan di beberapa negara Islam ? (2) Bagaimana ketentuan hukum pencatatan perkawinan dalam perspektif usul fikih?

\section{B. Pencatatan Perkawinan dalam Literatur Fikih Konvensional}

Di atas telah disebut, bahwa pembahasan tentang pencatatan perkawinan dalam kitab-kitab fikih konvensional tidak ditemukan. Sejauh ini hanya ditemukan konsep nikah sirri dalam kitab al-Mudawwanah, karangan Sahnūn (160-240/776-854), dan pembahasan tentang fungsi saksi dalam perkawinan oleh fuqaha lain. Masalah saksi yang oleh ulama lain menjadi sub bahasan tersendiri, oleh Sahnūn hanya disinggung ketika membahas status hukum nikah sirri. ${ }^{1}$ Hal ini memperkuat keyakinan, bahwa masalah pencatatan perkawinan memang erat hubungannya dengan masalah saksi (fungsi saksi) dalam perkawinan.

Dalam Kitab al-Mabsūt, karya alSarakhsi dinyatakan, menurut Hanafiyyah ('ulamāunā), saksi harus ada dalam perkawinan. Pendapat ini didasarkan oleh hadits. ${ }^{2}$ Untuk menolak pendapat Imam Malik, Ibn Abi Lailā dan 'Usmān al-Batta yang berpendapat saksi tidak masuk rukun perkawinan, tetapi yang menjadi rukun adalah pengumuman (i'lä), al-Sarakhsi mencatat :(i) hadis yang mengharuskan kehadiran empat unsur dalam akad nikah untuk sahnya perkawinan, yakni calon suami ( peminang), wali dan dua orang saksi, di tambah dengan (ii) aśar 'Umar yang tidak mengakui keabsahan perkawinan yang hanya dihadiri satu orang saksi. ${ }^{3}$ Sebagai konsekuensi dari pendapat Mālik, Ibn Abī Lailā dan 'Usmān al-Batta yang menekankan pengumuman di atas, kalau sudah diumumkan meskipun hanya kepada anak-anak dan orang gila nikahnya menjadi sah. Dasar yang mereka catat, seperti ditulis oleh alSarakhsi adalah hadis Nabi yang menyuruh mengumumkan perkawinan, dan tindakan Nabi yang menyuruh membunyikan pukulan-pukulan (gendang) sebagai isyarat salah satu cara mengumumkan. ${ }^{4}$ Berdasarkan hadis dan asar di atas, ulama tersebut berkesimpulan bahwa unsur yang menjadi batas boleh atau tidaknya perkawinan adalah ada atau tidaknya unsur usaha merahasiakan. Perkawinan yang ada unsur usaha merahasiakan, masuk kelompok usaha perkawinan yang tidak boleh (haram). Jalan keluarnya agar tidak masuk kelompok tersebut adalah perkawinan harus diumumkan (i'lān). Pengumuman tersebut berguna untuk menghindari tuduhan atau keraguan orang lain. ${ }^{5}$ Dasar yang ditulis Mālik 
untuk mengatakan bahwa kehadiran saksi dalam semua transaksi, termasuk dalam akad nikah, hanya bersifat sunnah (anjuran), adalah al-Qur'an surat alBaqarah (2) $282^{6}$ dan aț-Talāq (65):2. ${ }^{7}$

Menurut Imam Syäfii, saksi dalam perkawinan haruslah dua orang laki-laki. Sementara al-Sarakhsi membolehkan gabungan antara seorang laki-laki dan dua orang wanita. Bahkan menurut al-Sarakhsi, satu pria dan satu wanita pun pada dasarnya sah cukup untuk saksi perkawinan, hanya saja sebagai usaha preventif agar tidak menyesatkan dan tidak lupa, diperlukan satu orang lain lagi. Menurut al-Sarakhsi, pemikiran Imam Syāfi'i tersebut dikiaskan dengan masalah saksi dalam hal mu'amalah secara umum, dimana dalam kasus-kasus tertentu memang hanya dapat disaksikan kaum pria. ${ }^{8}$

Kehadiran saksi dalam

perkawinan menurut al-Kasāni adalah syarat sah perkawinan. Fungsi saksi dalam perkawinan ada dua, pertama, untuk menghindari adanya tuduhan zina, dan kedua, untuk menghindari terjadinya fitnah. Dengan saksi, berita perkawinan seseorang akan mudah disebarluaskan kepada masyarakat umum. Fungsi saksi dalam perkawinan berbeda dengan fungsi saksi dalam peristiwa hukum lain, seperti jual-beli. Dalam jual beli, saksi berfungsi untuk mengantisipasi jika para pihak ada yang lupa atau ada pihak yang mengingkari, maka saksi dalam jual beli hukumnya sunnah. ${ }^{9}$ Maksud al-Kassāni, saksi dalam perkawinan merupakan keharusan, sedang dalam kasus selain perkawinan hanya anjuran (sunnah). Adapun kehadiran saksi dalam perkawinan adalah ketika ijab-qabul dilaksanakan, sebab kehadiran saksi adalah syarat dapat terlaksananya rukun nikah tersebut. Menurut Khoirudin Nasution, al-Kassāni berusaha mengkompromikan pandangan Abū Hanifah dan Imam Mālik, di mana Abū Hanifah menekankan kehadiran saksi, sedangkan Imam Mālik menekankan pada fungsi saksi, yakni pengumuman. Al-Kassāni mengatakan, bahwa saksi harus ada dalam akad nikah, yang fungsinya sebagai sarana pengumuman atau untuk menyebarluaskan informasi tentang pernikahan tersebut. ${ }^{10}$

Terkait dengan saksi, suatu perkawinan bisa berstatus dikecam bahkan difonis tidak sah atau haram. Dalam kitab al-Mudawwanah, Imam Mālik membedakan antara perkawinan sirri (nikah al-sirri) dan nikah yang tidak disertai bukti (nikah bighair albayyinah). Nikah sirri adalah nikah yang secara sengaja dirahasiakan oleh pihakpihak yang terlibat dalam pernikahan tersebut. Hukum perkawinan seperti ini tidak sah. Sedangkan nikah yang tidak ada bukti tetapi diumumkan kepada khalayak ramai, maka hukumnya sah. ${ }^{11}$ Menurut Sahnūn, perkawinan yang ada bukti tetapi diminta untuk dirahasiakan, masuk kategori nikah yang tidak sah, sebaliknya, perkawinan yang tidak ada bukti tetapi tidak dirahasiakan masuk kelompok perkawinan yang sah, dengan catatan disaksikan kemudian. Bahkan kalau pun banyak bukti tetapi ada usaha untuk merahasiakan, maka termasuk nikah fäsid (tidak sah). ${ }^{12}$ Dari penjelasan ini bisa dipahami bahwa nikah sirri adalah perkawinan yang ada usaha dari para pihak (mempelai atau saksi) untuk merahasiakan. Jika demikian, maka unsur pokok yang menyebabkan haramnya nikah sirri adalah adanya usaha untuk merahasiakan perkawinan tersebut oleh para pihak yang terlibat. Dengan demikian, unsur pengumuman menjadi penentu sah tidaknya perkawinan.

Nikah sirri, menurut Umar ibn Khattab termasuk jenis nikah yang dilarang. Hal ini didasarkan pada hadits dan asar 'Umar

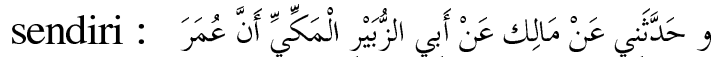

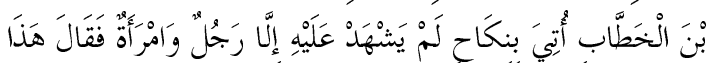
13

Menurut Ibnu Qudāmah (w. 620 H), dari Mazhab Hanbali, saksi dalam perkawinan 
harus ada berdasarkan hadits nabi di atas. Saksi dalam perkawinan menurutnya tidak boleh seorang zimmi, tidak wanita, tetapi boleh seorang buta, dengan syarat mengetahui benar suara orang yang melakukan akad sama kira-kira dengan pengetahuan orang yang tidak buta. ${ }^{14}$ Menurut Ibnu Qudāmah, saksi harus ada, namun mengenai pengumuman terjadinya perkawinan kepada orang lain hukumnya hanyalah sunnah.

\section{Ketentuan Pencatatan Perkawinan dalam Perundang-undangan Perkawinan Muslim dan Status Hukumnya}

1. Undang-undangan Perkawinan di Indonesia

Undang-undang Republik Indonesia yang pertama kali mengatur masalah pencatatan perkawinan adalah UU No. 22 Tahun 1946 tentang Pencatatan Nikah, Talak dan Rujuk yang berlaku untuk daerah Jawa dan Madura. Kemudian UU ini berdasarkan UU No. 32 Tahun 1954 diberlakukan untuk seluruh wilayah Indonesia. Pasal 1 ayat (1) menegaskan adanya keharusan pengawasan terhadap pelaksanaan pernikahan, talak dan rujuk dari Pegawai Pencatat Nikah. ${ }^{15}$ Bagi perkawinan tanpa pengawasan Pegawai Pencatatan Nikah dianggap melanggar dan karena itu dikenakan hukuman. ${ }^{16}$ Namun pelanggaran terhadap keharusan mencatatkan perkawinan ini hanya bersifat administrasi, artinya pencatatan perkawinan tidak menjadi syarat sah nikah. $^{17}$ Mengenai tujuan adanya pencatatan ini ditegaskan dalam penjelasan pasal 1 ayat (1), yaitu agar mendapatkan kepastian hukum dan ketertiban. $^{18}$

Ketentuan tentang pencatatan perkawinan ini kemudian dituangkan lagi dalam Undang-Undang No. 1 Tahun 1974 tentang Perkawinan, yang pelaksanaannya secara efektif berlaku sejak 1 Oktober 1975. Pasal 2 ayat (2) UU No. 1 Tahun 1974 menyatakan: "tiap-tiap perkawinan dicatat menurut peraturan Perundangundangan yang berlaku". Sedangkan mengenai teknis pencatatan perkawinan dan lembaga/instansi yang diberi kewenangan melakukan tugas tersebut dijelaskan dalam Peraturan Pemerintah RI No.9 Tahun 1975 pasal 2 dan 3 sebagai berikut:

Pencatatan perkawinan dalam Kompilasi Hukum Islam di Indonesia dijelaskan pada pasal 5 sampai dengan 7. Pada pasal 5 ayat (1) disebutkan bahwa tujuan pencatatan perkawinan adalah agar terjamin ketertiban perkawinan bagi masyarakat Islam, dan Pasal 6 ayat [2] menyatakan bahwa perkawinan yang tidak dalam pengawasan PPN dianggap tidak mempunyai kekuatan hukum. Sedangkan pasal 7 ayat (1) membicarakan akta nikah sebagai bukti telah terjadi perkawinan, ayat (2) dalam hal perkawinan tidak dapat dibuktikan dengan akta nikah, maka dapat dilakukan itsbat nikah (penetapan nikah) oleh Pengadilan Agama.

Ketentuan-ketentuan dari beberapa perundang-undangan dan KHI tentang pencatatan perkawinan di atas tampak bahwa fungsi pencatatan perkawinan sekadar urusan administrasi, bukan merupakan syarat sah sebuah perkawinan. Hanya UU No. 1 Tahun 1974 yang menyatakan, bahwa peraturan perundang-undangan termasuk unsur yang harus dipenuhi untuk sahnya akad nikah.

Perkawinan seseorang yang dengan sengaja tidak dilangsungkan di hadapan Pejabat Pencatat Nikah, alias tidak dicatatkan kepada lembaga pemerintah yang berwenang untuk itu, dalam pasal 141 draft Rancangan Undang-undang Hukum Terapan Peradilan Agama bidang Perkawinan 
yang disusun Departemen Agama RI tahun 2006 - yang sampai tahun 2010 ini belum diundangkan - akan dikenai sanksi pidana dengan pidana denda paling banyak Rp. 6.000.000 [enam juta rupiah] atau hukuman kurungan paling lama 6 [enam] bulan. Demikian juga dalam pasal 144, seseorang yang menceraikan istrinya tidak di depan sidang pengadilan akan mendapatkan sanksi pidana sebagaimana pada pasal 141 di atas.

Meskipun ketentuan pidana ini mengundang reaksi pro-kontra dari masyarakat, namun jika dinalar secara jernih, semua ketentuan pidana terkait dengan nikah sirri [bagi pernikahan pertama maupun untuk poligami] sesungguhnya mengandung nilai maslahat yang besar bagi semua anggota keluarga (suami, istri dan anak-anak), berupa terwujudnya ketertiban dan terhindarnya anggota keluarga dari pengabaian hak mereka.

2. Undang-undang Perkawinan di Malaysia

Di Malaysia, hukum keluarga (hukum perkawinan) yang digunakan sebanyak negara bagian di Malaysia, dan semuanya mengharuskan adanya pendaftaran/pencatatan perkawinan. ${ }^{19}$ Hanya dalam hal teknis pencatatannya saja yang sedikit ada perbedaan, yakni waktu dilakukannya pencatatan ada tiga. Namun pada prinsipnya sama, yakni pencatatan perkawinan dilakukan setelah akad nikah dilangsungkan. Dari teks-teks perundang-undangan Malaysia dapat dipahami bahwa pencatatan perkawinan hanya diposisikan sebagai masalah administrasi, tidak ada hubungannya dengan ketentuan sah tidaknya akad nikah (perkawinan). Dengan demikian sedikit agak berbeda, dalam perundang-undangan Indonesia masih ada kemungkinan status pencatatan perkawinan tidak sekedar syarat administrasi, bahkan pasal-pasal tentang pencatatan perkawinan bisa dipahami secara jama $i$ (utuh/keseluruhan) sebagai salah satu syarat sah sebuah perkawinan.

3. Undang-undang Perkawinan di Brunei Darussalam dan Singapura

Pemerintah

Brunei mewajibkan adanya pencatatan perkawinan dalam jangka waktu 7 hari setelah akad nikah dilaksanakan. Religious Council and Kadis Courts Chap 77, pasal 143 ayat (1) menyatakan : "Dalam jangka waktu tujuh hari setelah melakukan akad nikah para pihak diharuskan melaporkan perkawinan tersebut, yang boleh jadi para pasangan atau wali". Ayat (2), "Pencatat wajib memeriksa apakah seluruh persyaratan perkawinan sudah terpenuhi sebelum melakukan pencatatan". ${ }^{20}$ Pasal 180 menyatakan, "Seorang yang seharusnya tetapi tidak melaporkan perkawinan atau perceraian kepada pegawai pencatat adalah satu pelanggaran yang dapat mengakibatkan dihukum dengan hukuman penjara atau denda \$200".

Demikian juga Singapura mengharuskan pencatatan perkawinan, perceraian dan rujuk (AMLA pasal 102), dan bagi yang melanggar mendapatkan hukuman, baik para pihak maupun pegawai pencatat perkawinan (AMLA pasal $130)^{21}$

4. Undahg-undang di Syiria

Kalau dicermati, dalam UU No. 34 tahun 1975 pasal 40 ayat (1) didapati sesuatu yang menarik terkait dengan pencatatan perkawinan, bahwa formulir perkawinan harus disampaikan kepada Pegawai Pencatat Perkawinan, yang salah satu lampiran yang harus ada adalah keterangan dokter, bahwa yang bersangkutan tidak mengidap penyakit menular. ${ }^{22}$ Disamping itu ada ketentuan bahwa pernikahan harus dilakukan di pengadilan, 
meskipun masih ada kemungkinan melaksanakan perkawinan di luar pengadilan, yakni : (a) apabila seluruh persyaratan telah dipenuhi, atau (b) terhadap perkawinan orang hamil atau yang sudah melahirkan anak, dengan konsekuensi ada kemungkinan dikenakan hukuman. ${ }^{23}$ Dengan demikian, meskipun pernikahan di luar pengadilan masih dapat dilegalisasi, pihak yang bersangkutan bisa dikenakan hukuman pidana. Pemberian hukuman ini bisa dipahami sebagai upaya pemerintah memberikan efek jera pelaku perzinaan (yang mengakibatkan kehamilan di luar perkawinan yang sah), meskipun perempuan yang dizinai itu kemudian menjadi istrinya. Disamping itu secara psikologis akan tertanam pada diri remaja, jiwa yang taat peraturan dengan tidak menyepelekan persoalan perzinaan.

5. Undang-undang di Yordania

Pasal 17 ayat (a dan b) UU No. 61 Tahun 1976 mengharuskan adanya pencatatan perkawinan, dan bagi yang melanggar, baik bagi mempelai maupun pegawai pencatat nikah, akan mendapatkan hukuman. Pasal 17 ayat (a) menyatakan : "Mempelai laki-laki harus memohon kepada hakim atau wakilnya untuk mengadakan akad nikah, (b) Akad nikah harus dilakukan Pegawai Nikah yang bertanggung jawab kepada hakim sesuai dengan catatan (dokumen) resmi. Hakim mungkin mengambil alih tugas ini untuk kasuskasus tertentu dan dengan izin ketua Pengadilan". ${ }^{24}$

6. Undang-undang di Mesir

Egyptian Code of
Organization and Procedure for
Syari'a Courts of 1897 adalah UU
Mesir tentang Organisasi dan
Prosedur Berperkara di Pengadilan
tahun 1897, dimana ketentuan tentang

pencatatan perkawinan pertama kali diatur dalam sebuah perundangundangan. Ditegaskan dalam UU ini, bahwa pemberitahuan satu perkawinan atau perceraian harus dibuktikan dengan catatan (akta). Hanya saja, pembuktian ini boleh (cukup) dengan oral yang diketahui secara umum oleh para pihak yang berperkara. Ketentuan ini kemudian diperluas dalam perundang-undangan tahun 1909-1910, dan diubah tahun 1913, dimana pada pasal 101 disebutkan, perdebatan seputar perkawinan dan perceraian yang diadukan salah satu pasangan atau orang ketiga tidak akan ditanggapi kecuali ada bukti yang meyakinkan kebenarannya. Menurut peraturan tahun 1911, pembuktian harus dengan catatan resmi pemerintah (official document) atau tulisan tangan dan tanda tangan dari seorang yang sudah meninggal. Dalam peraturan tahun 1931 lebih dipertegas lagi dengan kata-kata harus ada bukti resmi (akta) dari pemerintah (official certificate). ${ }^{25}$

7. Undang-undang di Iran dan Irak Iran menetapkan setiap perkawinan dan perceraian harus dicatatkan. Seseorang yang melakukan pernikahan atau perceraian dan tidak dicatatkan kepada petugas pencatat nikah, maka dianggap melakukan pelanggaran terhadap peraturan perundangundangan. $^{26}$

Sedangkan Irak, disamping mengharuskan adanya pencatatan perkawinan, juga mewajibkan melampirkan surat keterangan dokter bahwa yang bersangkutan tidak mengidap penyakit menular, sebagaimana UU Syiria. Pasal 10 UU Irak tahun 1984 menyebutkan : "Perkawinan (akad nikah) harus dicatatkan pada pengadilan berwenang, yang di dalamnya termasuk (1) identitas mempelai, jumlah mahar, dan surat keterangan 
ada atau tidaknya hal yang membatalkan perkawinan, (2) surat keterangan dokter, yang membuktikan bahwa yang bersangkutan tidak mengidap penyakit menular". ${ }^{27}$

8. Undang-undang di Tunisia dan AlJazair

Tunisia menetapkan, perkawinan hanya dapat dibuktikan dengan catatan resmi dari pemerintah (official document). Dalam pasal 4 UU Tunisia No. 40 tahun 1957 dinyatakan ; "Perkawinan seharusnya dibuktikan dengan catatan resmi. Perkawinan yang dilakukan di luar pengadilan seharusnya dibuktikan dengan cara yang berlaku di Tunisia, yakni sesuai dengan peraturan tentang akad nikah". ${ }^{28}$

Sedangkan Al-Jazair hanya menetapkan bahwa akad nikah boleh dilakukan setelah mendapat pengesahan dari pegawai berwenang. Dalam perundang-undangan Al-Jazair tidak ditemukan penjelasan tentang status pencatatan perkawinan. Pasal 18 UU Al-Jazair No 84-11 Tahun 1984 menyatakan : "Akad nikah dilakukan setelah mendapat pengesahan dari pegawai yang berwenang sesuai dengan pasal $9 \mathrm{UU}$ ini". $^{29}$

9. Undang-undang di Maroko dan Libya Maroko mengharuskan adanya pencatatan perkawinan, bahkan menyaratkan tanda tangan dua notaris untuk absahnya pencatatan perkawinan. Namun UU Maroko tidak menjelaskan status perkawinan tanpa pencatatan dan ancaman bagi orang yang tidak melakukan pencatatan perkawinan. ${ }^{30}$

Demikian juga pasal 5 UU Libya No. $10 \quad$ Tahun 1984 menyatakan : "Perkawinan harus dibuktikan dengan catatan resmi atau ketetapan pengadilan". Namun tidak dijelaskan status pencatatan perkawinan dan akibat hukum perkawinan yang tidak dicatatkan. ${ }^{31}$

\section{Pencatatan Perkawinan dalam Sorotan Metodologis}

Ketika pencatatan perkawinan ternyata dalam kehidupan berkeluarga dirasa penting dan memiliki fungsi yang signifikan, dan terbukti aturan tentang pencatatan perkawinan dimuat dalam perundang-undangan keluarga di berbagai negara, maka para ulama mencoba memberikan landasan metodologis perlunya pencatatan perkawinan yang dibuktikan dengan akta nikah. Ada beberapa ayat al-Qur'an yang bisa dijadikan kajian pembicaraan mengenai pencatatan perkawinan, antara lain QS. Al-Baqarah [2]: 282

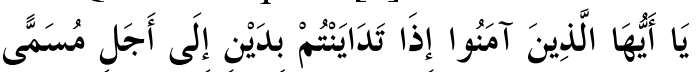

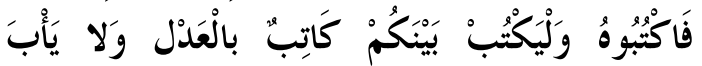

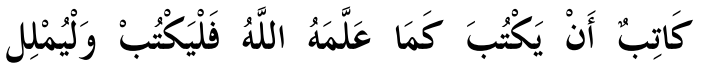

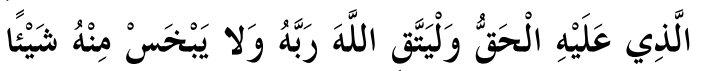

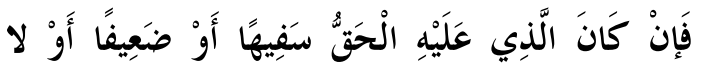

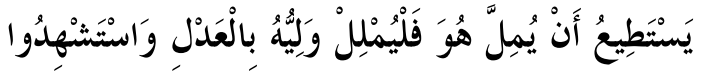

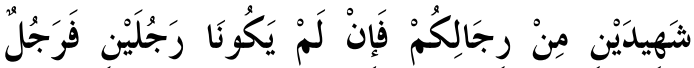

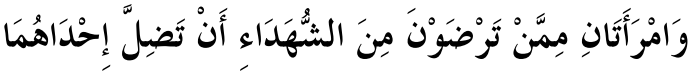

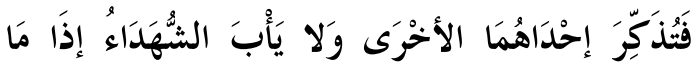

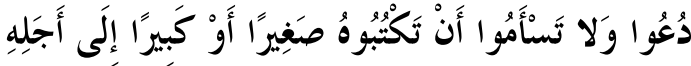

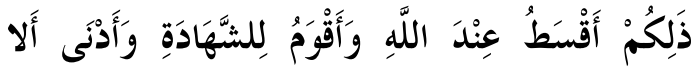

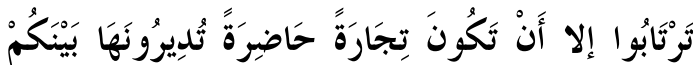

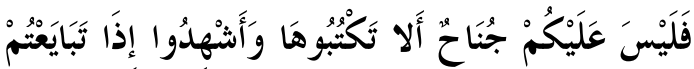

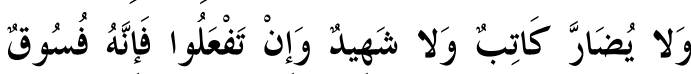

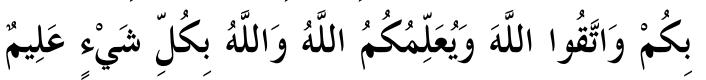

$(Y \wedge Y)$

Hai orang-orang yang beriman, apabila kamu bermu'amalah tidak secara tunai untuk waktu yang ditentukan, hendaklah kamu menuliskannya. dan hendaklah seorang penulis di antara kamu menuliskannya dengan benar. dan 
janganlah penulis enggan menuliskannya sebagaimana Allah mengajarkannya, maka hendaklah ia menulis, dan hendaklah orang yang berhutang itu mengimlakkan (apa yang akan ditulis itu), dan hendaklah ia bertakwa kepada Allah Tuhannya, dan janganlah ia mengurangi sedikitpun daripada hutangnya. jika yang berhutang itu orang yang lemah akalnya atau lemah (keadaannya) atau dia sendiri tidak mampu mengimlakkan, maka hendaklah walinya mengimlakkan dengan jujur, dan persaksikanlah dengan dua orang saksi dari orang-orang lelaki (di antaramu). Jika tak ada dua oang lelaki, maka (boleh) seorang lelaki dan dua orang perempuan dari saksi-saksi yang kamu ridhai, supaya jika seorang lupa maka yang seorang mengingatkannya. Janganlah saksi-saksi itu enggan (memberi keterangan) apabila mereka dipanggil; dan janganlah kaти јети menulis hutang itu, baik kecil maupun besar sampai batas waktu membayarnya. Yang demikian itu, lebih adil di sisi Allah dan lebih menguatkan persaksian dan lebih dekat kepada tidak (menimbulkan) keraguanmu. (Tulislah mu'amalahmu itu), kecuali jika mu'amalah itu perdagangan tunai yang kamu jalankan di antara kamu, maka tidak ada dosa bagi kamu, (jika) kamu tidak menulisnya.

Dan persaksikanlah apabila kamu berjual beli; dan janganlah penulis dan saksi saling sulit menyulitkan. Jika kamu lakukan (yang demikian), maka sesungguhnya hal itu adalah suatu kefasikan pada dirimu, dan bertakwalah kepada Allah; Allah mengajarmu; dan Allah Maha mengetahui segala sesuatu. (QS. Al-Baqarah [2]: 282).

Perintah ayat ini secara redaksional ditujukan kepada orangorang beriman, tetapi yang dimaksud adalah mereka yang melakukan transaksi hutang-piutang, bahkan lebih khusus adalah orang yang berhutang. Ini agar orang yang memberi piutang lebih tenang, sebab penulisan piutang itu dilakukan terutama oleh orang yang berhutang. Menurut M. Quraish Shihab, setiap kata yang dihimpun dari huruf dain (dal, y $\overrightarrow{a^{\prime}}$ dan nün), termasuk kata "tadāyantum" menggambarkan adanya hubungan antara dua pihak, salah satunya berkedudukan lebih tinggi dari yang lain. Yakni ada hubungan timbal balik atau dengan kata lain sebagai mu'amalah. ${ }^{32}$

Masih menurut M. Quraish Shihab, perintah menulis utang-piutang dipahami oleh banyak ulama sebagai anjuran, bukan kewajiban. ${ }^{33}$ Demikian praktek para sahabat nabi saat itu, demikian juga yang terbaca pada ayat berikutnya. Pandangan seperti ini bisa dipahami, karena kondisi saat ayat tersebut diturunkan, di kalangan sahabat masih bisa dibilang belum banyak yang pandai tulis menulis. Jika ini perintah wajib tentu sangat menyulitkan. Namun demikian jika dicermati dari isyarat penggunaan kata $i \bar{z} \bar{a}$ apabila pada penggalan ayat tersebut, yang lazim digunakan untuk menunjukkan kepastian akan terjadinya sesuatu, ${ }^{34}$ maka perintah menulis dari yang bersifat anjuran biasa bisa menjadi anjuran wajib. Kepastian akan terjadinya sesuatu boleh jadi berupa pelanggaran salah satu pihak jika tidak dibuat sebuah akta (perjanjian) yang menjadi bukti otentik terjadinya transaksi utang-piutang di antara mereka. Penggalan ayat selanjutnya menggambarkan adanya pembuatan perjanjian tersebut dilakukan secara adil, maksudnya dengan benar, tidak menyalahi ketentuan Allah dan perundang-undangan yang berlaku dalam masyarakat, dan tidak juga merugikan salah satu pihak yang bermu'amalah, sebagaimana dipahami dari kata adil dan di antara kamu.

Ayat ini mendahulukan penyebutan "adil" dari pada penyebutan "pengetahuan yang diajarkan Allah". Ini karena keadilan, disamping menuntut adanya pengetahuan bagi yang akan berlaku adil, juga karena seseorang yang adil tapi tidak mengetahui, keadilannya 
akan mendorong dia untuk belajar. Berbeda dengan yang mengetahui tetapi tidak adil. Ketika itu pengetahuannya akan dia gunakan untuk menutupi ketidakadilannya. Ia akan mencari celah hukum untuk membenarkan penyelewengan dan menghindari sanksi. Demikian M. Quraish Shihab. ${ }^{35}$

Penggalan ayat selanjutnya "jangan enggan menulisnya" sebagai tanda syukur, sebab "Allah telah mengajarnya, maka hendaklah ia menulis", mengingatkan kepada para penulis (yang memiliki kemampuan), bahwa di atas pundaknya lah tanggung jawab penulisan itu dibebankan. Walaupun pesan ayat ini dinilai oleh banyak ulama sebagai anjuran, tetapi ia menjadi wajib jika tidak ada selainnya yang mampu, dan pada saat yang sama, jika suatu hak dikhawatirkan akan terabaikan.

Setelah menjelaskan hukum penulisan utang-piutang, penulis, kriteria dan tanggung jawab, maka dikemukakan tentang siapa yang mengimlakkan kandungan perjanjian yang telah disepakati untuk ditulis. Ia adalah yang berhutang, kenapa? Karena dia pada posisi yang lemah, jika yang mengimlakkan yang memberi hutang, bisa jadi suatu ketika yang berhutang akan mengingkarinya. Berdasarkan nalar yang logis dia tidak akan mengingkari, sebab yang mengimlakkan adalah yang berhutang sendiri.

Baru kemudian ayat ini berbicara masalah persaksian, baik dalam tulis menulis maupun lainnya. Saksi terdiri dari dua orang pria atau satu pria dan dua perempuan, lalu Allah mengingatkan kepada saksi - sebagaimana Allah mengingatkan kepada penulis - supaya tidak enggan apabila mereka dipanggil. Setelah berbicara saksi, ayat ini masih mengulangi lagi mengenai penulisan utang-piutang, namun penekanannya pada utang yang sedikit (jumlahnya kecil), sebab biasanya perhatian tidak diberikan kepada utang yang kecil ini.
Menurut Ahmad Rofiq, ayat mudāyanah (al-Baqarah : 282) di atas mengisyaratkan bahwa adanya bukti otentik sangat dibutuhkan untuk menjaga kepastian hukum. Redaksinya secara jelas menggambarkan bahwa pencatatan lebih didahulukan dari pada kesaksian, yang dalam perkawinan menjadi rukun. ${ }^{36}$ Memang patut dipertanyakan mengenai alasan mengapa para ulama dalam hal pencatatan perkawinan dan membuktikannya dengan akta nikah, tidak dianalogikan kepada ayat mudāyanah tersebut.

Dengan memperhatikan ayat mudāyanah di atas, secara metodologis, status hukum pencatatan perkawinan dalam perundang-undangan hukum keluarga muslim di berbagai Negara Islam yang mayoritas mengharuskan adanya pencatatan itu, bisa didasarkan pada metode qiyas (deduksi analogis), yaitu perintah membuat bukti otentik secara tertulis pada transaksi utangpiutang (jual-beli) yang tidak tunai. Pencatatan perkawinan (pembuatan akta nikah) bisa dianalogikan dengan perintah pembuatan bukti tercatat (perjanjian) utang-piutang karena keduanya memiliki kesamaan 'illat, yakni terabaikannya hak bagi para pihak yang melakukan transaksi jika tidak ada akta perjanjian. Artinya dalam rangka memberikan kepastian hukum bagi para pihak yang terlibat dalam transaksi.

Sebagaimana masalah utangpiutang, perkawinan sebagai sebuah peristiwa hukum yang mengakibatkan hak dan kewajiban bagi pihak-pihak yang terkait dengannya dan segala implikasi yang ditimbulkannya, maka pencatatan perkawinan juga menjadi suatu yang penting dalam rangka mewujudkan kepastian hukum. Menurut hemat penulis, qiyass yang digunakan di sini adalah qiyas awlawi, artinya sesuatu yang dianalogkan (al-far'u) itu dalam posisi yang seharusnya lebih mendapat perhatian utama ketimbang hukum sandarannya (al-așl). Karena hukum 
perkawinan lebih banyak memiliki implikasi hukum lain seperti hukum nasab dan hukum waris jika dibandingkan dengan hukum utangpiutang.

Selain metode qiyas, pencatatan perkawinan bisa didekati dengan metode Sadd al-Żari'ah. Sadd = menutup, alzari'ah $=$ wasilah/jalan ke suatu tujuan. Sadd al-zari'ah = menutup jalan kepada suatu tujuan. Secara istilah, Abd Karim Zaidan mendefinisikan :

أنه من باب منع الوسائل المؤديــة الى المفاســـ (menutup

jalan (sarana) yang membawa kepada kebinasaan atau kejahatan). ${ }^{37}$

Sebagaimana perjanjian (akta) utang-piutang dan sertifikasi benda wakaf, akta nikah merupakan sarana untuk membuktikan eksistensi perkawinan. Artinya akta nikah bisa dipahami sebagai instrument (wasilah) untuk menjaga hak dan kewajiban seluruh anggota keluarga dalam bingkai yuridis formal. Memenuhi hak seseorang adalah wajib, jika tanpa akta nikah, hak salah satu anggota keluarga tidak dapat terjamin, maka mengadakan akta nikah hukumnya juga wajib. Hal ini sesuai

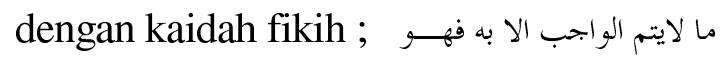
(suatu kewajiban tidak akan sempurna tanpa adanya sesuatu yang lain, maka sesuatu tersebut menjadi wajib adanya). Kaidah fikih yang lain ;

( الامر بشيئ أمر بو سائله للوسائل حكم المقاصـــ (perintah

terhadap sesuatu berarti perintah untuk mengadakan perantaranya/wasilah (alat untuk mencapainya), dan hukum yang ada pada perantara sama dengan hukum yang ada pada tujuan). ${ }^{39}$

Berdasarkan kaidah fikih di atas, pencatatan nikah dilakukan sebagai tindakan preventif dari kemungkinan adanya tindakan pengabaian hak dari salah satu pihak. Upaya pemenuhan hak dan kewajiban dalam keluarga secara yuridis bisa dilakukan dengan membuat akta nikah. Pada posisi ini, akta nikah merupakan wasilah / instrument yuridis bagi pemenuhan hak dan kewajiban dalam keluarga.

Dari penjelasan di atas, bisa dipahami bahwa pencatatan perkawinan adalah perbuatan yang pada dasarnya mubah dan membawa kemaslahatan yang dengan perbuatan tersebut kemudharatan (terabaikannya suatu hak) dapat ditutup. Atau, dengan bukti otentik, pengingkaran terhadap peristiwa hukum (perkawinan) dapat dihindarkan. Jadi adanya pencatatan perkawinan yang dibuktikan dengan akta nikah bisa menutup kemungkinan upaya pengingkaran salah satu pihak dalam pemenuhan kewajibannya, padahal tidak memenuhi kewajiban berarti melanggar aturan hukum.

Selain menggunakan metode qiyass dan Sadd al-Zari'ah, pencatatan perkawinan bisa dicari sandaran hukumnya dengan metode mașlahat almursalah (public interest). Mașlahat almursalah merupakan salah satu bentuk maslahah. Dalam kajian maslahah, dipahami bahwa seluruh hukum yang ditetapkan Allah atas hambaNya - dalam bentuk suruhan atau larangan - adalah mengandung maslahat. Di balik suruhan terdapat maslahat berupa manfaat bagi pelakunya baik secara langsung atau tidak, misalnya perintah shalat mengandung manfaat antara lain untuk ketenangan rohani dan kebersihan jasmani. Dan dibalik larangan terdapat maslahat berupa terhindarnya manusia dari kebinasaan atau kerusakan, misalnya, larangan minum minuman keras akan menghindarkan manusia dari mabuk yang bisa merusak akal.

$$
\text { Setiap perbuatan yang }
$$
mengandung kebaikan dalam pandangan manusia, maka biasanya untuk perbuatan itu terdapat hukum syara' dalam bentuk suruhan. Sebaliknya, pada setiap perbuatan yang dirasakan manusia mengandung kerusakan, maka biasanya untuk perbuatan itu ada hukum syara' dalam bentuk larangan. Kalau dicermati, al-Qur'an Surat al-Baqarah ayat 282 di 
atas dan An-Nur ayat 33 - yang akan dibahas nanti - yang terkait dengan persoalan pencatatan memakai bentuk perintah, hal ini bisa diduga keras bahkan dipastikan perintah itu mengandung maslahat.

Menurut al-Syātibi, metode maslahat al-mursalah sesungguhnya dalil qat' $i$, yang dibangun atas dasar metode induksi (istiqra'i). Dalil ini dibangun dari peristiwa-peristiwa yang bersifat individu (kasus-kasus) dalam masyarakat, kemudian ditarik kesimpulan secara umum. Misalnya, gambaran seorang istri (dengan nikah sirri) dan anak-anaknya, jika suatu saat menghadapi kenyataan ditinggal pergi oleh suaminya dan tidak diketahui entah dimana, sementara nafkah lahir tidak diberikan, apalagi nafkah batin, lebih-lebih lagi istri tidak memiliki pekerjaan dan harus menghidupi anak-anaknya, jika tidak memiliki salinan akta nikah, maka istri dan anak-anak tersebut tidak dapat mengajukan tuntutan haknya kepada suaminya, karena tidak memiliki sarana untuk mengajukan tuntutan ke pengadilan. Berbeda halnya jika ada salinan akta nikah, seorang istri dan anakanaknya dapat melakukan upaya hukum untuk mendapatkan haknya yang ditelantarkan.

Kasus-kasus seperti ini banyak terjadi di masyarakat kita terutama di masyarakat yang cara berfikirnya berorientasi pada fikih sentries. Mereka mengabaikan pencatatan perkawinan, dengan melakukan nikah sirri dan poligami liar, karena bagi mereka pencatatan perkawinan tidak diatur secara tegas oleh al-Qur'an dan sunnah, disamping itu mereka meyakini bahwa sahnya perkawinan hanya diukur dari pemenuhan syarat dan rukun perkawinan saja berdasarkan ketentuan fikih. Memang diakui tidak setiap nikah sirri mempunyai nasib sama sebagaimana gambaran di atas, namun yang jelas seorang istri tidak memiliki jaminan hukum akan haknya jika terjadi sesuatu yang tidak dikehendakinya.

Dalam kaidah hukum Islam, pencatatan perkawinan dan membuktikannya dengan akta nikah, sangat jelas mendatangkan maslahat bagi tegaknya rumah tangga. Ini sejalan لمرأ المفاسد مقدم على جلب المصساحل. dengan prinsip (menolak kemadharatan lebih didahulukan daripada memperoleh kemaslahatan)

Disamping ayat 282 al-Baqarah di atas, ada juga ayat yang memungkinkan bisa ditelaah kaitannya dengan pencatatan perkawinan, yakni ayat yang membicarakan anjuran kepada hamba sahaya menjaga dirinya dari perzinahan karena belum memiliki kemampuan untuk menikah sekaligus keinginan hamba sahaya yang menginginkan hak kemerdekaan dirinya, dengan meminta kepada tuannya untuk membuat perjanjian (al-kitabah). Yakni QS. AlNūr ayat 33 :

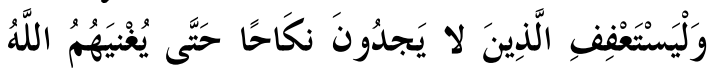

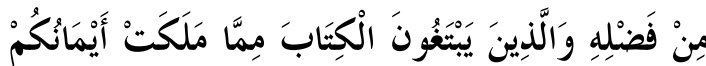

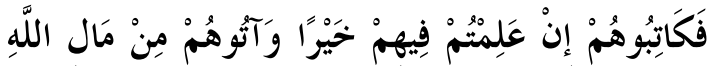

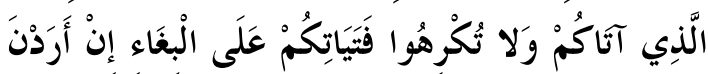

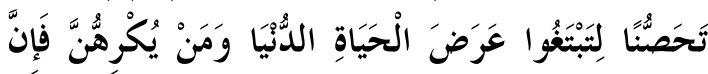

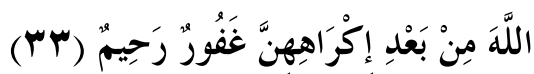

Dan hendaklah menjaga kesucian (diri)nya orang-orang yang tidak mampu kawin, sehingga Allah memampukan mereka dengan karunia-Nya. Dan budakbudak yang kamu miliki yang menginginkan perjanjian, hendaklah kamu buat perjanjian dengan mereka, jika kamu mengetahui ada kebaikan pada mereka, dan berikanlah kepada mereka sebahagian dari harta Allah yang dikaruniakan-Nya kepadamu. Dan janganlah kamu paksa budak-budak wanitamu untuk melakukan pelacuran, sedang mereka sendiri mengingini kesucian, karena kamu hendak mencari keuntungan duniawi. Dan Barangsiapa yang memaksa mereka, maka 
sesungguhnya Allah adalah Maha Pengampun lagi Maha Penyayang (kepada mereka) sesudah mereka dipaksa itu.

فكاتبوهم ان علمتم فـيهم Penggalan ayat خيرا (hendaklah kamu membuat perjanjian dengan mereka, jika kamu mengetahui ada kebaikan pada mereka, bisa dipahami adanya perintah kepada tuan untuk membuat perjanjian memerdekakan hamba sahayanya ketika sang tuan melihat ada nilai kebaikan (maslahah) pada mereka. Makna kebaikan di dalam ayat ini dipahami oleh M. Quraish Shihab, bahwa mereka akan mampu melaksanakan tugas dan memenuhi kewajiban mereka, tanpa menjadi pengemis serta mampu pula memelihara diri dan agama mereka. ${ }^{40}$

Ayat ini dimaksudkan oleh penulis untuk mendukung pemahaman bahwa sebuah perjanjian (bukti otentik) dari transaksi apapun termasuk pembuatan akta nikah dan akta pemerdekaan seorang hamba sahaya memiliki fungsi yang signifikan dalam rangka pemenuhan hak dan kewajiban bagi para pihak. Penulis memahami penggalan ayat "jika kamu mengetahui ada kebaikan pada mereka" sebagai alasan sebuah perjanjian yang dikehendaki hamba sahaya itu hendaknya diturutkan oleh tuannya. Karena dengan kemerdekaan yang diperoleh, seorang hamba akan mendapatkan nilai maslahat yang lebih besar, nilai kebebasan dan nilai diri secara manusiawi (karena hamba sahaya dinilai separoh dari orang merdeka). Karena itu pencatatan perkawinan yang juga banyak memberikan manfaat dan maslahat bagi para pihak, juga bisa dianalogkan dengan anjuran pembuatan akta perjanjian pemerdekaan hamba sahaya.

\section{E. Kesimpulan}

Berdasarkan uraian diatas dapat disimpulkan bahwa:
1. Ketentuan tentang pencatatan perkawinan sebagaimana dibahas dalam perundang-undangan perkawinan muslim tidak ditemukan pembahasannya dalam kitab-kitab fikih konvensional. Secara umum perundang-undangan perkawinan muslim kontemporer di beberapa negara mengharuskan pencatatan perkawinan, kecuali Al-Jazair yang hanya menyatakan bahwa nikah boleh dilakukan setelah mendapat pengesahan dari pegawai berwenang, tidak menjelaskan aturan pencatatan perkawinan. Namun mereka berbeda mengenai rincian keharusan pencatatan perkawinan tersebut. Jika dikelompokkan, mereka terkelompok menjadi tiga yaitu :

Pertama, kelompok negara yang menetapkan pencatatan sebagai satu kewajiban, dan pihak yang melanggar mendapat hukuman, atau perkawinannya tidak memiliki kekuatan hukum. Negara-negara yang masuk dalam kelompok ini antara lain : Indonesia, Brunei, Singapura, Mesir, Iran, Irak, Yordania, dan Tunisia.

Kedua, kelompok negara yang menjadikan pencatatan sebagai syarat administrasi, namun tidak menegaskan status dan akibat hukum perkawinan yang tidak dicatatkan. Antara lain negara Maroko, Libya, dan Lebanon.

Ketiga, negara yang masih mengakui perkawinan yang tidak dicatatkan meskipun mengharuskan pencatatan perkawinan. Hanya Syiria negara yang masuk tipologi ketiga ini.

2. Al-Qur'an dan sunnah tidak secara tegas menjelaskan mengenai pencatatan perkawinan. Namun status pencatatan perkawinan dalam perundang-undangan keluarga di berbagai negara, dapat dicarikan sandaran metodologisnya, yakni dengan minimal tiga metode : (1) metode qiyas (analogi), yakni 
menganalogikan dengan perintah membuat bukti otentik adanya transaksi utang-piutang secara tidak tunai (QS. Al-Baqarah :282), dan perintah membuat perjanjian bagi budak mukātab (QS. An-Nūr : 33), (2) metode sadd al-zari'ah dan (3) metode mașlahat mursalah.

\section{Endnotes}

1 Al-Imām Muhammad Sahnūn bin Sa'id at-Tanūkhi, al-Mudawwwanah al-Kubra (Beirūt: Dār Șadr,1323 H.), III, hlm. 194.

2 . Hadis ini bersumber dari Ibn 'Abbas' dalam at-Tirmizi, Sunan at- Tirmidzi, "Kitāb al-Nikāḥ" hadis no. 1022. Syams al-Din al-Sarakhsi, al-Mabsuț (Beirūt: Dār al- Ma'rūfah, 1409/1989), V, hlm. 30.

${ }^{3}$ Isyarat tidak mengakuinya adalah statement memberikan hukum rajam kepada yang bersangkutan قال عمر رضي الله عنه لا اتي برجل تـزوزج

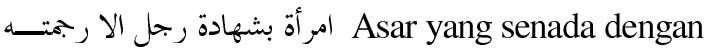

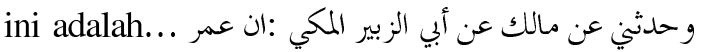

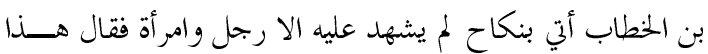
نكاح السر ولا أجيزه ولو كنت تقدمت فيه لرجمت بsarar ini bersumber dari az-Zubair, dalam Imam Malik, al-Muwatta', "Kitāb al-Nikāh", hadis no.982. AlSarakhsi, al-Mabsut t, V, hlm. 31.

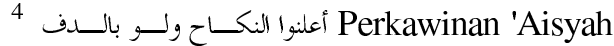
juga disertai dengan bunyi gendang-gendangan. Lihat al-Sarakhsi, al-Mabsụt, Juz V, hlm. 31. Dalam teks lain disebutkan أخبروا النكاح وأخفــوا الخخبــة (umumkanlah perkawinan dan sembunyikanlah pelamaran). Disebutkan hadis ini bersumber dari ad-Dailami dalam al-Firdaus, dari Ummu Salamah dalam al-Jämi' al-Kabïr dan dari

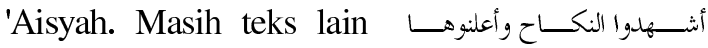
(saksikan dan umumkan perkawinan itu). Hadis ini bersumbeer dari al-Hasan bin Sufyan dalam al-Jazam. Oleh al-Ṭabrāni dari Habbar bin alAswad. Al-Tabrāni juga berasal dari al-Sāib bin Yazid al-Kindi. Oleh al-Suyūṭi di kelompokkan menjadi hadis Hasan Sebab munculnya (asbab alWurüd) kedua hadis ini sama, yakni berkenaan dengan kasus Habbar bin al-Aswad yang menikahkan puterinya cukup meriah dengan membunyikan genderang. Ternyata suara ini didengar oleh Nabi. Setelah Nabi mengetahui karena ada pesta perkawinan, muncullah sabda tersebut. Lihat Ibn Hamzah al-Husaini al-Hanafi al-Dimasyqā, Asbāb al-Wurūd: Latar Belakang Histories Timbulnya Hadis-hadis Rasul, terj.
H.M. Suwarta Wijaya dan Zafrullah Salim cet. Ke 2 (Jakarta Kalam Illahi, 1994), hlm. 209 dan 226. Lihat al-Tirmiżi, Sunan at-Tirmizzi, "Kitāb anNikāḥ", hadis no 1009; Ibn Mājah , Sunan Ibn Mājah, "Kitāb an-Nikāh", hadis no 1885.

${ }^{5}$ Syams al-Dīn al-Sarakhsī, al-Mabsūt, V, hlm. 31.

6 "Hai orang-orang yang beriman, apabila kamu bermu'amalah tidak secara tunai untuk waktu yang di tentukan hendakklah kamu menuliskannya."

7 "......Dan persaksikanlah dengan dua orang yang adil di antara kamu." hlm. 32.

${ }^{8}$ Syams al-Dīn al-Sarakhsī, al-Mabsūț, V,

${ }^{9}$ Dasar penetapan keharusan saksi dalam perkawinan menurut al-Kasāni adalah hadits yang mengharuskan adanya saksi dan kecaman perkawinan tanpa bukti sebagai perkawinan yang tidak sah. Mengenai hadits yang menyuruh mengumumkan perkawinan, menurut al-Kasāni, sejalan dengan tuntutan kehadiran saksi. Terhadap hadits tentang perintah mengadakan bunyibunyian gendang, dipahami al-Kasāni sebagai anjuran (sunnah) mengadakan pengumuman tambahan, disamping pengumuman dengan saksi. Imam 'Alā' al-Dỉn Abỉ Bakr bin Mas'ūd al-Kāsāni, Kitab Bada'i as-Sana'i fi Tartib al-Syara'i (Beirut: Dār al-Fikr, 1417/1996), II, hlm. 376377.

10 Khoirudin Nasution, Status Wanita di Asia Tenggara: Studi Terhadap Perundangundangan Perkawinan Muslim Kontemporer di Indonesia dan Malaysia, (Jakarta: INIS LeidenJakarta, 2002), hlm. 143.

192-194.

${ }^{11}$ Saḥnūn, Al-Mudawwanah, Juz III, hlm.

${ }^{12} \mathrm{Ibid}, \mathrm{hlm} .193$.

${ }^{13}$ Imam Malik, Al-Muwața', "Kitāb al-

Nikāh", hadits No. 982.

$14 \mathrm{Abu}$ Muhammad 'Abdullah bin Ahmad bin Qudāmah, Al-Mughnī wa al-Syarh al-Kabĩr (Beirut: Dār al-Fikr, 1984), VII: 340.

${ }^{15}$ Pasal 1 ayat (1) UU No. 22 Tahun 1946 berbunyi : "Nikah yang dilakukan menurut agama Islam, selanjutnya disebut nikah, diawasi oleg Pegawai Pencatatan Nikah yang diangkat oleh Menteri Agama atau oleh pegawai yang ditunjuk olehnya. Talak dan rujuk yang dilakukan menurut agama Islam, selanjutnya disebut talak dan rujuk, diberitahukan kepada Pegawai Pencatatan nikah".

${ }^{16}$ Pasal 3 ayat (1) UU No. 22 Tahun 1946 berbunyi : "Barang siapa yang melakukan akad nikah atau nikah dengan seorang perempuan tidak dibawah pengawasan pegawai yang dimaksudkan pada ayat (2) pasal 1 atau wakilnya, dihukum denda sebanyak-banyaknya Rp. 50 (lima puluh rupiah)". Pasal 4 berbunyi :"Hal-hal yang boleh 
dihukum seperti pada pasal 3 dipandang sebagai pelanggaran".

17 "Ancaman dengan denda sebagai tersebut pada ayat 1 dan 3 pasal 3 Undang-undang ini bermaksud supaya aturan administrasi ini diperhatikan, akibatnya sekali-kali bukan, bahwa nikah, talak dan rujuk itu menjadi batal karena pelanggaran". Demikian teks penjelasannya.

${ }^{18}$ Penjelasan pasal 1 ayat (1): "Maksud pasal ini ialah agar nikah, talak dan rujuk menurut agama Islam dicatat agar mendapatkan kepastian hukum. Dalam Negara yang teratur segala hal-hal yang bersangkut paut dengan penduduk harus dicatat, sebagai kelahiran, pernikahan, kematian dan sebagainya. Lagi pula perkawinan bergandengan rapat dengan waris-mal-waris sehingga perkawinan perlu dicatat menjaga jangan sampai ada kekacauan".

${ }_{19}$ Misalnya, pasal 25 UU Pinang 1985 : "Perkahwinan selepas tarikh yang ditetapkan tiaptiap orang yang bermastautin dalam negeri pulau Pinang dan perkahwinan tiap-tiap orang yang tinggal di luar negeri tetapi bermastautin dalam negeri Pulau Pinang hendaklah didaftarkan mengikut Enakmen ini". Selain pasal ini juga dapat dilihat pada pasal 23 UU Serawak 1981, pasal 25 UU Negeri Sembilan 1983, pasal 25 UU Selangor 1984, pasal 25 UU Persekutuan 1984, pasal 23 UU Perak 1984, dan pasal 25 UU Pahang 1987 ,

${ }^{20}$ Tahir Mahmood, Family Law Reform in The Muslim World (Bombay: N.M. TRIPATHIPVT.LTD, 1972), hlm. 207.

${ }^{21}$ Khoirudin Nasution, Status Wanita, hlm. 153.

22 Bunyi pasal 40 ayat (1), "Formulir perkawinan harus diserahkan kepada hakim yang berwenang, yang memuat (1) identitas diri mempelai, (2) akta lahir, (3) keterangan dokter bahwa yang bersangkutan tidak mengidap penyakit menular, (4) surat izin boleh nikah bagi anggota militer, (5) persetujuan dari polkam untuk orang luar Syiria". Lihat J.N.D. Anderson, "The Syrian Law of Personal Status", dalam Bulletin in The School of Oriental and African Studies, No. 17 (1955), hlm. 37.

${ }^{23}$ Pasal 40 ayat (2) UU No. 34 Tahun 1975 menyatakan : "Perkawinan di luar pengadilan tidak mungkin dilakukan kecuali seluruh prosedur yang ditetapkan telah dipenuhi, kecuali dalam kasus anak lahir atau hamil lebih dahulu sebelum nikah, sertifikat perkawinan dapat diberikan tanpa harus memenuhi prosedur tersebut, meskipun tidak menutup kemungkinan dikenakan hukuman pidana". Lihat Dawoud Sudqi El-Alami dan Doreen Hinchcliffe, Islamic Marriage and Divorce Laws (London, The Hague, Boston: Kluwer Law International, 1996), hlm. 222.
${ }^{24}$ Lihat Tahir Mahmood, Personal Law in Islamic Countries, (New Delhi: Academy of Law and Religion, 1987), hlm. 79-80. 153

${ }^{25}$ Khoirudin Nasution, Status Wanita, hlm.

${ }^{26}$ Tahir Mahmood, Personal Law, hlm.

215

${ }^{27} \mathrm{Ibid}, \mathrm{hlm} .58$

${ }^{28}$ Lihat El-Alami dan Hincchliffe, Islamic Marriage and Divorce Laws, hlm. 240, J.N.D. Anderson, "The Tunisian Law of Personal Status" dalam International and Comparative Law Quarterly 7 (April, 1958), hlm. 267.

${ }^{29}$ Tahir Mahmood, Personal Law, hlm. 21.

30 The Code of Personal Status Tahun 1957/58, pasal 42 ayat (6), "Catatan (dokumen) perkawinan harus memuat: (1) identitas mempelai, yang meliputi nama mempelai, umur, tempat tinggal (domisili), orang tua, nama wali dan bahwa mereka memenuhi syarat melakukan akad nikah, (2) semua unsur yang dibutuhkan untuk akad nikah, yang meliputi tanggal dan tempat akad nikah, pemberitahuan oleh mempelai dan wali tentang mahar, (3) identitas lengkap mempelai wanita, yang meliputi apakah dia masih perawan atau janda, anak yatim atau masih punya bapak, kalau yatim apakah sudah mempunyai wali atau wali hakim, kalau janda apakah akibat perceraian atau karena ditinggal mati suami, dan apakah masa 'iddah sudah habis atau belum, (4) sertifikat dan nomor seri dari pegawai yang berwenang, (5) jumlah mahar dan tentang pembayaran tunai atau kredit, dan (6) tanda tangan dua notaries yang sudah diakui hakim". El Alami dan Hinchcliffe, Islamic Marriage and Divorce Laws, hlm. 206.

${ }^{31}$ El-Alami dan Hincchliffe, Islamic Merriage and Divorce Laws, hlm. 182.

${ }^{32}$ M.Quraish Shihab, Tafsir Al-Mishbah: Pesan Kesan dan Keserasian al-Qur'an (Jakarta: Lentera Hati, 2007), Volume 1, cet. Ke-11, hlm. 603.

33 Lihat juga Muhammad Syarbini alKhatib, Tafsir al-Siraj al-Munir, Juz 1 hlm. 413. Sumber : Maktabah Syamilah.

${ }^{34}$ M.Quraish Shihab, Tafsir Al-Mishbah: Pesan Kesan dan Keserasian al-Qur'an, Volume 1, hlm. 604.

${ }^{35} \mathrm{Ibid}, 604-605$.

36 Ahmad Rofiq, Hukum Islam di Indonesia (Jakarta: Raja Grafindo Persada, 1995), hlm. 119.

${ }^{37}$ Satria Efendi, Usul Fikih (Jakarta :

Kencana, 2006), hlm. 172.

${ }^{38}$ Ali Hasaballah, Ușü al-Tasyrì al-Islämī (Kuwait: Dār al-Ma'ārif, t.t.), hlm. 317-318.

${ }^{39}$ Amir Syarifudin, Usul Fikih 2 (Jakarta: Logos, 1999), hlm. 398.

${ }^{40}$ M. Quraish Shihab, Tafsir al-Mishbah, Volume 9, hlm. 339. 


\section{DAFTAR PUSTAKA}

Al-Dimasyqā, Ibn Hamzah al-Ḥusaini alHanafi. Asbab al-Wurud: Latar Belakang Histories Timbulnya Hadis-hadis Rasul. terj. H.M. Suwarta Wijaya dan Zafrullah Salim. cet. Ke 2. Jakarta Kalam Illahi, 1994.

Efendi, Satria. Usul Fikih. Jakarta :

Kencana, 2006.

El-Alami dan Hincchliffe. "Islamic Marriage and Divorce Laws". J.N.D. Anderson "The Tunisian Law of Personal Status". Dalam. International and Comparative Law. Quarterly 7, April, 1958.

El-Alami, Dawoud Sudqi dan Doreen Hinchcliffe. Islamic Marriage and Divorce Laws. London, The Hague, Boston: Kluwer Law International, 1996.

Hasaballah, Ali. Usul al-Tasyri alIslämi. Kuwait: Dār al-Ma'ārif, t.t.

Ibn Qudāmah, Abu Muhammad 'Abdullah bin Ahmad. AlMughni wa al-Syarh al-Kabir. Beirut: Dār al-Fikr, 1984.

J.N.D. Anderson. "The Syrian Law of Personal Status". Dalam Bulletin in The School of Oriental and African Studies. No. 17, 1955.

Al-Kasāni, Imam 'Alā' al-Dỉn Abi Bakr bin Mas'ūd. Kitabb Badäi as-
Sana’i fi Tartib al-Syara'i'. Beirut: Dār al-Fikr, 1417/1996.

Al-Khatib, Muhammad Syarbini. Tafsir al-Siraj al-Munir. CD Program Maktabah Syamilah.

Mahmood, Tahir. Family Law Reform in The Muslim World. Bombay: N.M. TRIPATHIPVT.LTD, 1972.

Mahmood, Tahir. Personal Law in Islamic Countries. New Delhi: Academy of Law and Religion, 1987.

Nasution, Khoirudin. Status Wanita di Asia Tenggara: Studi Terhadap Perundang-undangan

Perkawinan Muslim

Kontemporer di Indonesia dan Malaysia. Jakarta: INIS Leiden-Jakarta, 2002.

Rofiq, Ahmad. Hukum Islam di Indonesia. Jakarta: Raja Grafindo Persada, 1995.

Al-Sarakhsi, Syams al-Din. Al-Mabsūt. Beirūt: Dār al- Ma'rūfah, 1409/1989.

Shihab, M.Quraish. Tafsir Al-Mishbah: Pesan Kesan dan Keserasian al-Qur'an. Jakarta: Lentera Hati, 2007.

Syarifudin, Amir. Usul Fikih 2. Jakarta: Logos, 1999.

Al-Tanūkhì, Al-Imām Muhammad Saḥnūn bin Sa'id. $A l$ Mudawwwanah al-Kubrā. Beirūt: $\quad$ Dār $\quad$ Șadr,1323 H. 